\title{
Efektivitas Pelaksanaan Standar Proses dalam Kurikulum 2013 pada Pembelajaran Fisika di Kecamatan Kota Tambolaka dan Loura Kabupaten Sumba Barat Daya
}

\author{
Melkianus Suluh ${ }^{1}$, Monika Bili ${ }^{2}$ \\ ${ }^{1,2}$ Program Studi Pendidikan Fisika, STKIP Weetebula
}

\author{
*Melkianus Suluh: \\ Program Pendidikan Fisika; \\ STKIP Weetebula, Sumba Barat Daya; \\ Email: smelkieinstein@gmail.com
}

\begin{abstract}
Abstrak: Penelitian ini bertujuan untuk mengatahui 1) pandangan guru terhadap pelaksanaan proses pembelajaran, 2) kesesuaian perencanaan proses pembelajaran dengan pelaksanaannya dalam proses pembelajaran. Penelitian ini merupakan penelitian deskriptif kuantitatif dengan pendekatan korelasional. Sampel penelitian yang digunakan adalah guru-guru fisika yang mengajar di SMA sebanyak 11 orang yang diambil menggunakan teknik purposive sampling. Teknik pengumpulan data menggunakan instrument wawancara, angket, dokumentasi dan observasi. Adapun hasil penelitian adalah 1) Pandangan guru terhadap pelaksanaan proses pembelajaran sangat baik, 2) Perencanaan proses pembelajaran belum sepenuhnya sesuai dengan pelaksanaannya dalam proses pembelajaran.

Kata Kunci: Kurikulum 2013, Pelaksanaan Proses Pembelajaran, Pembelajaran Fisika SMA
\end{abstract}

Abstract: This study aims to find out 1) the teacher's view of the implementation of the learning process, 2) the suitability of the planning of the learning process with its implementation in the learning process. This research is a quantitative descriptive study with a correlational approach. The research sample used was physics teachers who teach in high school as many as 11 people who were taken using purposive sampling technique. Data collection techniques using interview instruments, questionnaires, documentation and observation. The results of the research are 1) The teacher's view of the implementation of the learning process is very good, 2) The planning of the learning process is not fully in accordance with its implementation in the learning process.

Key word: Curriculum 2013, Implementation of the Learning Process, High School Physics Learning.

\section{PENDAHULUAN}

Pelaksanaan proses pembelajaran pada kurikulum 2013 mengacuh pada pendekatan ilmiah (scientific approach) dimana dalam konteks ini siswa dituntun agar lebih aktif, kreatif, inovatif dan lebih produktif dalam melakukan observasi, bertanya, menalar, mengkomunikasikan dan menyimpulkan apa yang mereka peroleh atau apa yang mereka ketahui setelah menerima materi pembelajaran. Melalui Kegiatan tersebut peserta didik diharapkan memiliki kompetensi sikap, keterampilan, dan pengetahuan yang jauh lebih baik. Disinilah guru berperan besar dalam mengimplementasikan kurikulum 2013 dalam proses pembelajaran.

Peran guru dalam mengimplementasikan Kurikulum 2013 dimulai ketika guru mulai merencanakan proses pembelajaran, melaksanakan proses pembelajaran hingga pada tahap evaluasi. Pada tahap ini, kemampuan guru akan sangat berdampak terhadap keberhasilan impelemtasi pembelajaran. Hal ini disampaikan oleh Kurniasih (2015: 20) bahwa salah satu aspek yang mempengaruhi proses dan hasil belajar peserta didik adalah kompetensi yang dimiliki guru dalam mengajar dan membimbing peserta didik.

Selain kemampuan guru dalam mengajar, pengalaman seorang guru dalam mengajar juga 
merupakan salah satu faktor yang sangat penting dalam proses pembelajaran. Guru yang memiliki pengalaman yang baik akan sangat mudah dalam mengimplementasikan pendekatan ilmiah baik dalam kegiatan perencanaan maupun dalam kegiatan pembelajaran di kelas. Menurut Uno (2008:2) perencanaan adalah suatu cara yang dibuat agar suatu kegiatan dapat berjalan yang disertai dengan berbagai langkah yang antisipatif guna memperkecil kemungkinan kesalaha yang akan dibuat. Dengan kata lain bahwa perencanaan proses pembelajaran merupakan suatu kerangka acuan atau pedoman bagi guru dalam melaksanakan proses pembelajaran.

Pengalaman adalah sesuatu yang pernah dialami, dirasakan, dan ditanggung dan sebagainya. Mengajar berasal dari kata "ajar" yang artinya petunjuk yang diberikan agar diketahui dan dituruti. Dalam Kamus Besar Bahasa Indonesia (KBBI) elektronik, mengajar merupakan memberi pelajaran. Jadi pengalaman mengajar adalah sebagian dari pemahaman seseorang terhadap hal-hal yang pernah dialami dan dirasakan dalam mengajar, sehingga hal tersebut terlebih dahulu telah dikuasai baik itu dari segi pengetahuan, keterampilan dan lain sebagainya yang terdapat dan menyatuh dalam dirinya. Guru yang baik akan mampu menemukan pengalaman-pengalaman baru selama mengajar sehingga meningkatkan pengetahuan dan keterampilan yang dimilikinya.

Satu hal yang penting dan perlu diperhatikan dalam proses pembelajaran adalah kesesuaian perencanaan pembelajaran dan pelaksanaannya. Hal tersebut penting karena apa yang telah dirancang atau direncanakan oleh guru harus benar-benar diterapkan juga dalam pelaksanaan proses pembelajaran. Pemahaman seorang guru harus ditingkatkan sehingga dengan demikian guru mampu melaksanakan dengan baik apa yang ditelah direncanakannya. Selain itu, hal yang yang perlu diperhatikan adalah pandangan guru terhadap pelaksanaan proses pembelajaran.

Pandangan atau persepsi guru dapat berarti cara guru melihat dan menilai sesuatu yang telah dan sedang dialami. Persepsi dalam arti umum adalah pandangan seseorang terhadap sesuatu yang akan membuat respon bagaimana dan dengan apa seseorang bertindak. Persepsi dari bahasa latin perception, percipio yang adalah tindakan menyusun, mengenali, dan menafsirkan informasi sensoris guna memberikan gambaran dan pemahaman tentang lingkungan.

\section{Metode Penelitian Jenis Penelitian}

Jenis penelitian ini adalah penelitian deskriptif kuantitatif dengan pendekatan korelasional.

\section{Lokasi dan waktu Penelitian}

Penelitian ini dilaksanakan di SMA Kecamatan Kota Tambolaka dan Loura Kabupaten Sumba Barat Daya tahun ajaran 2019/2020. Penelitian ini dilaksanakan mulai bulan Juni - September 2020.

\section{Subyek Penelitian}

Subyek yang digunakan dalam penelitian ini adalah guru-guru fisika yang mengajar di SMA yang diambil dengan teknik purposive sampling. Jumlah guru yang menjadi subyek penelitian 11 orang dengan sasaran guru yang mengajar menggunakan kurikulum 2013.

\section{Teknik dan Pengumpulan Data}

Pengumpulan data dalam penelitian ini dilakukan dengan teknik observasi, dokumentasi, dan angket. Teknik observasi dengan cara melakukan observasi secara langsung dengan guru saat proses pembelajaran, teknik dokumentasi dilakukan dengan menilai dokumen RPP yang dibuat oleh guru dengan berdasarkan indikator penilaian yang telah dibuat peneliti.

\section{Teknik Analisis Data}

Teknik analisis data yang digunakan dalam penelitian ini adalah analisis deskriptif kuantitatif dengan pendekatan korelasional dari Spearman. Analisis deskriptif digunakan untuk memberikan gambaran hasil penelitian dari dari variabel penelitian. Sedangkan, analisis korelasi spearman digunakan untuk mengetahui hubungan antar variabel yang dikorelasikan. Data dari hasil observasi dan hasil analisis dokumen dianalisis secara deskriptif kuantitatif dengan mengadaptasi kriteria dari Djemari Mardapi (2008, p. 123). Berikut ditampilkan kriteria pengkategorian dari setiap aspek penelitian pada tabel 1 di bawah ini.

Tabel 1. Kategorisasi Penilaian

\begin{tabular}{|c|c|c|c|}
\hline & & $\begin{array}{r}\text { Rumus } \\
Y>\bar{y}+15 c D\end{array}$ & Kategori \\
\hline & \multicolumn{2}{|c|}{$X \geq \bar{X}+1,5 S B_{x}$} & Sangat Baik/Selalu \\
\hline & \multicolumn{2}{|c|}{$\bar{X}+1,5 S B_{x}>X \geq \bar{X}$} & Baik/Kadang-kadang \\
\hline & \multicolumn{2}{|c|}{$\bar{X} \geq X \geq \bar{X}-1,5 S B_{x}$} & Cukup Baik/Pernah \\
\hline & \multicolumn{2}{|c|}{$X<\bar{X}-1,5 S B_{x}$} & Sangat rendah/Tidak Pernah \\
\hline \multicolumn{4}{|c|}{ Keterangan } \\
\hline $\bar{X}$ & $=$ & \multicolumn{2}{|l|}{ Rerata skor } \\
\hline$S B_{x}$ & $=$ & \multicolumn{2}{|c|}{ Simpangan baku ideal $=1 / 6$ (skor tertinggi-skor terendah) } \\
\hline $\mathrm{X}$ & $=$ & \multicolumn{2}{|c|}{ Mean ideal =1/2 (skor tertinggi-terendah) } \\
\hline
\end{tabular}




\section{HASIL DAN PEMBAHASAN}

\section{A. Data Hasil Observasi}

Berikut ini adalah data hasil observasi yang membahas tentang kemampuan guru dalam melaksanakan proses pembelajaran. Data mengenai kemampuan guru dalam melaksanakan proses pembelajaran diperoleh dengan melakukan observasi dengan menggunakan instrument observasi. Intrumen tersebut sebelum digunakan, di validasi oleh validator ahli dan validator praktisi. Rangkuman hasil observasi kemampuan guru dalam melaksanakan proses pembelajaran fisika dapat dilihat pada Tabel 2 berikut ini.

Tabel 2 Rangkuman Kemampuan guru melaksanakan pembelajaran fisika

\begin{tabular}{|c|c|c|}
\hline Frekuensi & Persentase (\%) & Kategori \\
\hline 8 & $72,73 \%$ & Baik \\
\hline 3 & $27,27 \%$ & Cukup Baik \\
\hline
\end{tabular}

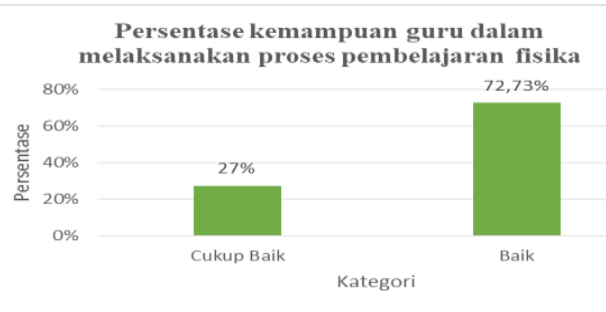

m Persentase

Grafik. 1 kemampuan guru melaksanakan pembelajaran.

\section{B. Data Hasil Dokumentasi}

Berikut adalah data hasil dokumentasi yang membahas kemampuan guru dalam merencanakan proses pembelajaran. Data itu, dinilai dengan menggunakan instrumen dokumentasi yang telah divalidasi oleh validator ahli dan validator praktisi. Instrumen dokumentasi yang dinilai adalah perangkat rencana pelaksanaan pembelajaran. Pada Tabel 3 ditampilkan hasil analisis kemampuan guru merencanakan proses pembelajaran fisika.

Tabel 3. Rangkuman Kemampuan guru merencanakan pembelajaran fisika

\begin{tabular}{|c|cc|}
\hline Frekuensi & Persentase & Kategori \\
\hline 2 & $18,18 \%$ & Sangat Baik \\
\hline 6 & $54,55 \%$ & Baik \\
\hline 3 & $27 \%$ & Cukup Baik \\
\hline
\end{tabular}

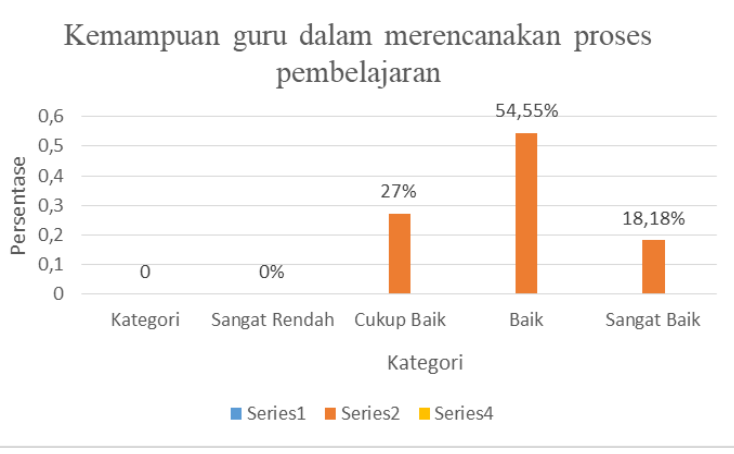

\section{Data Hasil Analisis Angket}

Berikut ini adalah data hasil analisis angket yang membahas tentang pandangan guru terhadap pelaksanaan proses pembelajaran. Data mengenai pandangan guru terhadap pelaksanaan proses pembelajaran diperoleh dengan menggunakan instrument angket. Instrumen tersebut sebelum digunakan, terlebih dahulu telah divalidasi oleh validator ahli dan validator praktisi. Tabel 4 berikut menampilkan hasil analisis pandangan guru dalam melaksanakan proses pembelajaran fisika.

Tabel 4. Rangkuman pandangan guru terhadap pelaksanaan proses pembelajaran fisika pada kurikulum 2013

\begin{tabular}{|c|c|c|}
\hline Frekuensi & Persentase & Kategori \\
\hline 9 & $81,82 \%$ & Selalu \\
\hline 2 & 18,18 & $\begin{array}{c}\text { Kadang- } \\
\text { Kadang }\end{array}$ \\
\hline
\end{tabular}

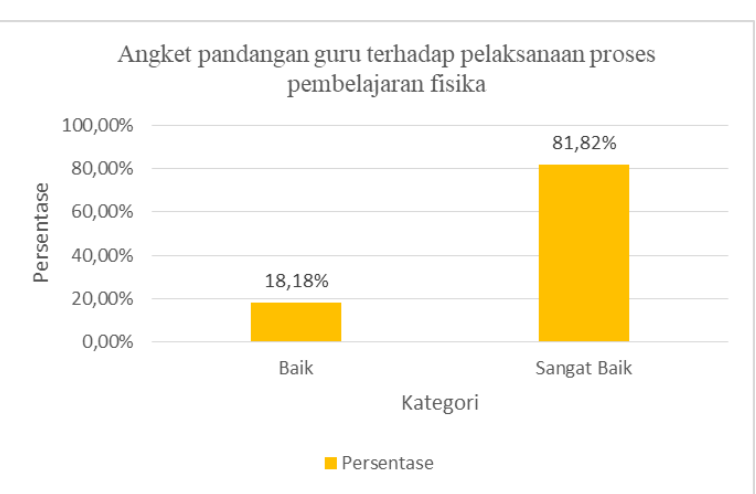

\section{Analisis Korelasi}

Untuk mengetahui hubungan antar variabel digunakan analisis korelasi, yang dikembangkan oleh Spearman dengan bantuan program SPSS 16 dengan Taraf signifikan yang digunakan dalam penelititan ini adalah sebesar 0,05 .

(1) Hubungan pengalaman mengajar dengan kemampuan guru dalam merencanakan proses pembelajaran fisika pada kurikulum 2013. Data hasil analisis korelasi dapat dilihat pada tabel 5 berikut. 
Tabel 5. Hubungan pengalaman mengajar dengan kemampuan guru dalam merencanakan proses pembelajaran fisika pada kurikulum 2013

\begin{tabular}{|c|c|c|c|c|}
\hline \multicolumn{5}{|c|}{ Correlations } \\
\hline & & & $\begin{array}{l}\text { Pengalaman } \\
\text { Mengajar }\end{array}$ & $\begin{array}{c}\text { Kemampuan } \\
\text { Guru Dalam } \\
\text { Merencanakan } \\
\text { Proses } \\
\text { Pembelajaran }\end{array}$ \\
\hline \multirow[t]{6}{*}{ Spearman's tho } & \multirow[t]{3}{*}{$\begin{array}{l}\text { Pengalaman } \\
\text { Mengajar }\end{array}$} & $\begin{array}{l}\text { Correlation } \\
\text { Coefficient } \\
\end{array}$ & 1.000 & .362 \\
\hline & & Sig. (2-tailed) & & .273 \\
\hline & & $\mathrm{N}$ & 11 & 11 \\
\hline & \multirow{3}{*}{$\begin{array}{l}\text { Kemampuan Guru } \\
\text { Dalam } \\
\text { Merencanakan } \\
\text { Proses } \\
\text { Pembelajaran }\end{array}$} & $\begin{array}{l}\text { Correlation } \\
\text { Coefficient } \\
\end{array}$ & .362 & 1.000 \\
\hline & & Sig. (2-tailed) & .273 & \\
\hline & & $\mathrm{N}$ & 11 & 11 \\
\hline
\end{tabular}

Berdasarkan data Tabel 5 diketahui bahwa pengalaman mengajar guru tidak berkorelasi secara signifikan dengan kemampuan guru dalam merencanakan proses pembelajaran fisika pada kurikulum 2013. Hal ini dapat diartikan bahwa pengalaman yang dimiliki guru tidak berpengaruh terhadap kemampuan guru merencakan proses pembelajaran fisika.

(2) Hubungan pengalaman mengajar dengan kemampuan guru dalam melaksanakan proses pembelajaran fisika pada kurikulum 2013. Data hasil analisis korelasi dapat dilihat pada Tabel 6 berikut.

Tabel 6. Hubungan pengalaman mengajar dengan kemampuan guru dalam melaksanakan proses pembelajaran fisika pada kurikulum 2013

\begin{tabular}{|c|c|c|c|c|}
\hline \multicolumn{5}{|c|}{ Correlations } \\
\hline & & & $\begin{array}{l}\text { Pengalaman } \\
\text { Nengaier }\end{array}$ & $\begin{array}{c}\text { Kemampuan Guru } \\
\text { Dalam } \\
\text { Melaksanakan } \\
\text { Proses } \\
\text { Pembelaiaran }\end{array}$ \\
\hline \multirow[t]{6}{*}{ Spearman's sho } & \multirow[t]{3}{*}{ Pengalaman Mengajer } & Correlation Coefficicent & 1.000 & .184 \\
\hline & & Sig. (2tataled) & & .588 \\
\hline & & $N$ & 11 & 11 \\
\hline & \multirow{3}{*}{$\begin{array}{l}\text { Remamplyan Guru } \\
\text { Dalam Melalasanalan } \\
\text { Proses Pembelaiaran }\end{array}$} & Correlation Coefficicent & .184 & 1.000 \\
\hline & & Sig. (2t-tailed) & .588 & \\
\hline & & $\vec{N}$ & 11 & 11 \\
\hline
\end{tabular}

Berdasarkan data tabel 6 diketahui bahwa pengalaman mengajar guru tidak berkorelasi dengan kemampuan guru dalam melaksanakan proses pembelajaran artinya bahwa tidak ada hubungan antara pengalaman mengajar guru dengan kemampuannya dalam melaksanakan proses pembelajaran fisika pada kurikulum 2013.

(3) Hubungan pengalaman mengajar dengan

kemampuan guru merencanakan dan melaksanakan pembelajaran. Hasil korelasi dapat dilihat pada Tabel 7 berikut.
Tabel 7 Hubungan pengalaman mengajar dengan kemampuan guru dalam merencanakan dan melaksanakan proses pembelajaran fisika pada kurikulum 2013

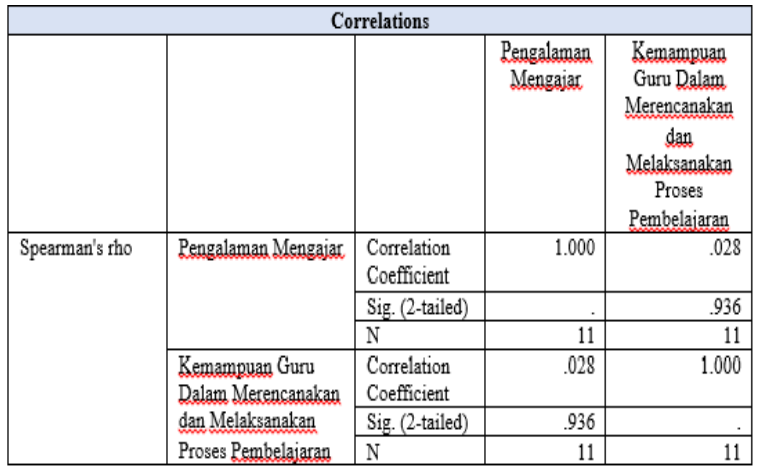

Dari data tabel diatas diketahui bahwa pengalaman mengajar dengan kemampuan guru dalam merencanakan dan melaksanakan proses pembelajaran fisika pada kurikulum 2013 tidak berkorelasi secara signifikan.

(4) Hubungan kesesuaian perencanaan proses pembelajaran dengan pelaksanaannya dalam proses pembelajaran fisika pada kurikulum 2013. Hasil korelasi dapat dilihat pada Tabel 8 berikut.

Tabel 8. Hubungan kesesuaian perencanaan proses pembelajaran dengan pelaksanaannya dalam proses pembelajaran

\begin{tabular}{|c|c|c|c|c|}
\hline \multicolumn{5}{|c|}{ Correlations } \\
\hline & & & \begin{tabular}{c|} 
Kemampuan \\
Guru Dalam \\
Merencanalan \\
Proses \\
Pembelajaran \\
\end{tabular} & $\begin{array}{l}\text { Kemampuan } \\
\text { Guru Dalam } \\
\text { Melaksanakan } \\
\text { Proses } \\
\text { Pembelajaran }\end{array}$ \\
\hline \multirow[t]{6}{*}{ Spearman's tho } & \multirow{3}{*}{$\begin{array}{l}\text { Kemampuan Guru } \\
\text { Dalam } \\
\text { Merencanakan } \\
\text { Proses } \\
\text { Pembelajaran }\end{array}$} & $\begin{array}{l}\text { Correlation } \\
\text { Coefficient }\end{array}$ & 1.000 & .265 \\
\hline & & Sig. (2-tailed) & & .430 \\
\hline & & $\mathrm{N}$ & 11 & 11 \\
\hline & \multirow{3}{*}{$\begin{array}{l}\text { Kemampuan Guru } \\
\text { Dalam } \\
\text { Melaksanakan } \\
\text { Proses } \\
\text { Pembelaiaran }\end{array}$} & $\begin{array}{l}\text { Correlation } \\
\text { Coefficient }\end{array}$ & .265 & 1.000 \\
\hline & & Sig. (2-tailed) & .430 & \\
\hline & & $\mathrm{N}$ & 11 & 11 \\
\hline
\end{tabular}

Dari data tabel diatas dapat diketahui bahwa perencanaan pembelajaran yang dilakukan oleh guru tidak berkorelasi dengan pelaksanaan proses pembelajaran. Artinya bahwa tidak ada kesesuaian antara perencanaan pembelajaran dengan pelaksanannya di dalam proses pembelajaran.

\section{PEMBAHASAN}

\section{A. Kemampuan Guru dalam Melaksanakan Proses Pembelajaran}

Hasil observasi menunjukkan bahwa sebanyak $72,73 \%$ guru mampu melaksanakan proses pembelajaran fisika pada kurikulum 2013 dengan baik, sementara itu 27,27\% guru melaksanakan proses pembelajaran fisika pada kurikulum 2013 dengan cukup baik. Berdasarkan 
hasil analisis secara keseluruhan, pelaksanaan proses pembelajaran fisika telah terlaksana dengan baik. Dalam kegiatan pelaksanaan proses pembelajaran terdapat tiga langkah kegiatan yang dilakukan yaitu: Kegiatan Pendahuluan, kegiatan inti, dan kegiatan penutup.

Berdasarkan hasil observasi di dalam kelas, dapat diketahui masih terdapat beberapa hal yang belum terlaksana dengan efektif. Pertama, pada kegiatan pendahuluan, tujuan pembelajaran jarang disampaikan oleh guru. Guru lebih cenderung memberikan apersepsi dan menjelaskan konsep umum materi yang disampaikan. Kedua, pada kegiatan menanya, terdapat beberapa guru yang tidak memberikan kesempatan kepada peserta didik untuk mengajukan pertanyaan sebagai umpan balik dari pemecahan masalah. Ketiga, pada kegiatan mengasosiasi/menalar, terdapat beberapa guru yang tidak menjelaskan hubungan materi dengan kehidupan nyata yang ada disekitar. Keempat, pada tahap mengkomunikasikan, sangat jarang guru menyampaikan tahapan-tahapan dalam mengerjakan soal ataupun pengamatan, dan jarang memberikan atau mengambil kesimpulan dari materi yang telah dijelaskan. Kelima, pada kegiatan penutup, manfaat dari materi pembelajaran tidak pernah disampaikan oleh guru. Dalam kegiatan tindak lanjut pembelajaran, guru selalu memberikan tugas tambahan kepada siswa tetapi tidak dijelaskan konsep atau cara pemilihan tahap-tahap menyelesaikan tugas tersebut sehingga terlihat bahwa siswa kadang mengalami kesulitan dalam penyelesaian tugas.

Beberapa hal yang tidak dilakukan tersebut diatas, dapat dikatakan bahwa kemampuan guru dalam melaksanakan proses pembelajaran fisika pada kurikulum 2013 belum efektif. Hal ini dilihat dari hasil observasi didalam kelas bahwa kadang siswa mengalami kesulitan dalam menyelesaikan persoalan dalam hal mengerjakan soal-soal yang diberikan guru karena kurangnya. penjelasan terhadap cara penyelesaian soal. Dari kegiatan pembelajaran yang telah dilakukan, berdasarkan tujuan kurikulum 2013 bahwa siswa diperlukan agar lebih aktif selama kegiatan pembelajarna berlangsung di dalam kelas, harusnya menjadi suatu perhatian khusus bagi guru agar lebih memperhatikan lagi keterlibatan siswa dalam pembelajaran sehingga siswa tidak monoton pada guru. Oleh karena itu, harusnya guru perlu memiliki kesiapan yang lebih baik lagi sebelum melakukan pembelajaran di dalam kelas.
Dari hasil analisis data observasi kemampuan guru dalam melaksanakan proses pembelajaran fisika pada kurikulum 2013 di SMA Se-Kecamatan Kota Tambolaka dan Loura Kabupaten Sumba Barat Daya telah terlaksana dengan baik. Hasil observasi tersebut dapat dilihat pada tabel 2 bahwa terdapat 8 orang guru mampu melaksanakan proses pembelajaran fisika pada kurikulum 2013 dengan baik dengan persentase sebesar $72,73 \%$ sementara itu terdapat 3 orang guru mampu melaksanakan proses pembelajaran fisika pada kurikulum 2013 dengan cukup baik.

\section{B. Kemampuan Guru dalam Merencanakan Proses Pembelajaran}

Berdasarkan hasil analisis data yang diperoleh dari penilaian dokumen RPP diketahui bahwa kemampuan guru dalam merencanakan proses pembelajaran, dalam hal ini membuat RPP termasuk dalam kategori baik. Namun demikian, masih diitemukan beberapa kekurangan yang harus diperbaiki guru. Dari hasil analisis pada tabel 3 menunjukkan bahwa sebanyak 18,18\% guru yang mampu merencanakan proses pembelajaran fisika dengan sangat baik, sementara itu 54,55 \% guru yang mampu merencanakan proses pembelajaran dengan baik, dan $27,27 \%$ guru yang mampu merencanakan proses pembelajaran fisika dengan cukup baik.

Kekurangan yang dimaksud diatas yang ditemukan yaitu dalam menyusun RPP guru hanya mencantumkan topik materi tanpa membuat rincian materi ataupun konsep dari materi yang akan dijelaskan. Langkah-langkah yang diterapkan dalam RPP lebih banyak pada aktivitas guru sehingga dapat ditafsirkan bahwa guru lebih monoton dalam pelaksanaan proses pembelajaran. Pengalokasian waktu masih kurang maksimal. Media pembelajaran yang ditampilkan dalam RPP tidak digunakan pada saat melakukan proses pembelajaran di dalam kelas. Masih terdapat guru yang menggunakan RPP yang sama. Namun berdasarkan hasil analisis data secara keseluruhan, dapat disimpulkan bahwa guru mampu menyusun rencana pembelajaran atau merencanakan proses pembelajaran dengan baik.

Terkait kekurangan yang telah disebutkan, disimpulkan bahwa penyusunan Rencana pembelajaran belum sepenuhnya dilakukan oleh guru. Dengan berbagai macam kegiatan pembekalan tentang perangkat pembelajaran seperti MGMP, IHT dan Workshop seharusnya menjadi sarana bagi guru untuk menerapkan betul bagaimana menyusun perangkat pembelajaran yang lebih baik sesuai dengan aturan kurikulum yang ada sehingga ada 
persiapan yang baik yang dilakukan guru sebelum melaksanakannya di dalam kelas.

Perencanaan pembelajaran membahas tentang beberapa aspek, yakni pengertian perencanaan itu sendiri, konsep, manfaat dan fungsi dari perencanaan pembelajaran. Perencanaan pembelajaran dapat diartikan sebagai suatu persiapan yang harus dilakukan oleh guru sebelum melaksanakan pembelajaran di dalam kelas untuk mencapai tujuan. Stenhouse (Hakim, 2009:238), mengemukakan bahwa "perencanaan pembelajaran yaitu persiapan mengelolah pembelajaran yang akan dilaksanakan dalam kelas untuk mencapai tujuan". Banghard dan Trull (Majid, 2009:15) pembelajaran adalah proses penyusunan materi pelajaran, penggunaan media pembelajaran, penggunaan pendekatan atau metode pembelajaran, dalam suatu alokasi waktu yang akan dilaksanakan pada masa satu semester yang akan datang untuk mencapai tujuan yang telah ditentukan.

Adapun tujuan dari membuat perencanaan pembelajaran, disampaikan oleh Martiyono (2012:23-24) tujuan membuat pembelajaran adalah 1) dapat menjadi landasan bagi duru dan peserta didik dalam mencapai kompetensi dasar dan indikator yang telah ditetapkan, 2) dapat menjadi gambaran dan menjadi acuan dalam melaksanakan proses pembelajaran, 3) berpengaruh terhadap peserta didik karena menggunakan pendekatan sistem. Sedangkan fungsi dari membuat perencanaan adalah 1) dapat menjadi petunjuk bagi guru dalam mencapai tujuan pembelajaran, 2) sebagai pola dasar dalam mengatur tugas dari setiap unsur yang terlibat, 3) dapat menjadi pedoman bagi setiap unsur yang terlibat, 4) sebagai alat ukur pencapaian pembelajaran, 5) sebagai bahan agar terjadi keseimbangan kerja dan 6) dapat menghemat waktu, tenaga, alat-alat dan biaya. Efektif dan tidaknya proses pembelajaran, kesiapan seorang guru menjadi hal yang paling utama dalam merencanakan pembelajaran. Perencanaan yang baik sangat berpengaruh dalam pelaksanaannya di dalam kelas. Sejalan dengan pernyataan tersebut, Muh. Sholeh juga menyatakan bahwa perencanaan pembelajaran sangat penting karena seorang guru sejenius apapun punya keterbatasan. Keterbatasan tersebut harus disadari sepenuhnya untuk diantisipasi agar ketika ditengah siswa-siswinya mampu menjadi motivator dalam proses pembelajaran yang mencerdaskan.

Dalam Permendikbud no 22 tahun 2016 juga disampaikan bahwa setiap pendidik pada satuan pendidikan berkewajiban menyusun RPP secara lengkap dan sistematis agar pembelajaran berlangsung secara interaktif, inspiratif, menyenangkan, menantang, efisien, memotivasi peserta didik untuk berpartisipasi aktif, serta memberikan ruang yang cukup bagi prakarsa, kreativitas, dan kemandirian sesuai dengan bakat, minat, dan perkembangan fisik serta psikologis peserta didik.

Berdasarkan beberapa penjelasan diatas, dapat disimpulkan bahwa sangat penting bagi seorang guru dalam merencanakan pembelajaran sebelum melaksanakannya di dalam kelas. Dengan adanya perencanaan yang dibuat, guru dapat mempertimbangkan aspek-aspek yang akan dicapai dalam pembelajaran yang meliputi tujuan, indikator, dan memberikan manfaat penting dari materi yang akan diajarkan, Serta membuat dokumen rencana pembelajaran sebagai pedoman setiap melakukan proses pembelajaran, sehingga dapat proses pembelajaran terstruktur dengan baik sesuai peruntukkannya.

Hal-hal yang harus diperbaiki dan ditingkatkan lagi oleh guru-guru dalam perencanaan pembelajaran adalah membuat RPP setiap melakukan pembelajaran, memperhatikan beberapa kekurangan yang ditemukan ketika melaksanakan pembelajaran sehingga menjadi acuan untuk mempersiapkan rencana pembelajaran yang lebih baik dan dapat digunakan pada proses pembelajaran selanjutnya.

\section{Pandangan Guru terhadap Pelaksanaan Pembelajaran}

Pandangan atau persepsi guru dapat berarti cara guru melihat dan menilai sesuatu yang telah dan sedang dialami. Persepsi dalam arti umum adalah pandangan seseorang terhadap sesuatu yang akan membuat respon bagaimana dan dengan apa seseorang bertindak. Persepsi dari bahasa latin perception, percipio yang adalah tindakan menyusun, mengenali, dan menafsirkan informasi sensoris guna memberikan gambaran dan pemahaman tentang lingkungan.

Dalam Kamus Besar Bahasa Indonesia (KBBI) persepsi merupakan suatu tanggapan (penerimaan) langsung dari sesuatu. Istilah persepsi biasanya digunakan untuk mengungkapkan tentang pengalaman terhadap suatu benda atau suatu kejadian yang dialami.

Kotler (2000) dan Istofiyani (2014) mengungkapkan bahwa, persepsi guru merupakan proses dimana seseorang memilih, mengorganisasikan, mengartikan masukan informasi untuk menciptakan suatu gambaran yang berarti dari dunia ini. 
Mangkunegara (dalam Arindita, 2002) berpendapat bahwa persepsi guru adalah suatu proses pemberian arti atau makna terhadap lingkungan, dalam hal ini persepsi mencakup penafsiran obyek, penerimaan stimulus (input), pengorganisasian stimulus, dan penafsiran terhadap stimulus yang telah diorganisasikan dengan cara memperngaruhi perilaku dan pembentukan sikap.

Persepsi guru merupakan proses aktif yang memegang peranan, bukan hanya stimulus yang mengenainya tetapi juga individu sebagai satu kesatuan dengan pengalamanpengalamannya, motivasi serta sikapnya yang relevan dalam menanggapi stimulus. Individu dalam hubungannya dengan dunia luar selalu melakukan pengamatan untuk dapat mengartikan rangsangan yang diterima dan alat indera dipergunakan sebagai penghubung antar individu dengan dunia luar.

Hasil analisis dari data Tabel 4 menunjukkan $81,82 \%$ guru menyatakan selalu melaksanakan proses pembelajaran fisika dengan baik, sementara itu $18,18 \%$ guru menyatakan kadang-kadang melaksanakan proses pembelajaran fisika dengan baik. Artinya bahwa guru memiliki persepsi atau pendangan yang baik dalam pelaksanaan proses pembelajaran. Guru memahami bagaimana pelaksanaan proses pembelajaran yang terjadi di sekolah. Pandangan guru terhadap pelaksanaan proses pembelajaran juga berdasarkan pengalaman guru selama menjadi tenaga pendidik sehingga apa yang harus direncanakan maupun dilaksanakan dalam proses pembelajaran, guru sudah bisa memiliki pemahaman tentang pengelolaan pembelajaran yang dilakukan.

\section{Hubungan Pengalaman Mengajar dengan Kemampuan Guru dalam Merencanakan Proses Pembelajaran Fisika pada Kurikulum 2013}

Data pada Tabel 5 menunjukkan bahwa tidak adanya korelasi atau hubungan pengalaman mengajar dengan kemampuan guru dalam merencanakan proses pembelajaran fisika pada kurikulum 2103. Tidak berkorelasinya kedua aspek tersebut dilihat dari nilai signifikansi 0,27 lebih besar dari Taraf Signifikansi yaitu 0,05. Artinya bahwa pengalaman mengajar guru tidak memiliki pengaruh terhadap kemampuan guru dalam merencanakan proses pembelajaran fisika pada kurikulum 2013.

Berdasarkan hasil analisis diatas, dapat diketahui bahwa bagaimana pun pengalaman mengajar seorang guru, dan berapa lama pun seorang guru mengabdikan dirinya dalam dunia pendidikan, bukan menjadi sebuah jaminan bahwa guru tersebut memiliki kemampuan dalam merencanakan proses pembelajaran fisika pada kurikulum 2013.

Sesuai dengan hasil analisis dokumen RPP dan lamanya guru mengajar, ternyata guru yang belum lama mengabdikan diri dalam proses pembelajaran lebih cenderung mampu merencanakan proses pembelajaran fisika dengan kategori sangat baik. Sedangkan guru dengan jangka waktu yang lama tergolong dalam kategori baik, dan beberapa diantaranya masih tergolong cukup baik. Ini berarti kemampuan guru dalam merencanakan pembelajaran tidak bisa diukur dari berapa lama guru tersebut mengajar melainkan berapa besar motivasi yang dimiliki oleh guru itu sendiri, seberapa jauh kemampuannya untuk terus belajar dan memiliki semangat dalam merencanakan proses pembelajaran yang lebih baik lagi sesuai dengan aturan kurikulum yang berlaku. Sehingga yang perluh ditingkatkan lagi oleh guru adalah kualitas pengetahuan/profesional guru itu sendiri. Seperti yang dikatakan oleh Zulfadewina (2018) dalam penelitiannya mengatakan bahwa peningkatan profesionalisme guru sudah sewajarnya dilakukan, tidak hanya pemerintah tapi dari guru itu sendiri juga harus punya kemauan keras untuk bisa lebih profesional sehingga tujuan pendidikan nasional dapat tercapai.

\section{E. Hubungan Pengalaman Mengajar dengan Kemampuan Guru dalam Melaksanakan Proses Pembelajaran Fisika pada Kurikulum 2013}

Berdasarkan data pada Tabel 6 diketahui bahwa hubungan pengalaman mengajar guru dengan kemampuan guru dalam melaksanakan proses pembelajaran fisika pada kurikulum 2013 tidak berkorelasi secara signifikan. Tidak ada korelasi antara kedua aspek tersebut dilihat dari nilai signifikansi 0,58 lebih besar dari Taraf Signifikansi 0,05 . Ini berarti bahwa pengalaman mengajar guru tidak memiliki pengaruh terhadap kemampuan guru dalam melaksanakan proses pembelajaran fisika pada kurikulum 2013.

Dari data hasil analisis diatas diketahui bahwa kemampuan guru dalam melaksanakan proses pembelajaran fisika tidak bergantung pada pengalaman mengajar atau lamanya guru tersebut mengajar. Tetapi bagaimana guru tersebut memiliki kesiapan dan mampu mengelolah kelas dengan baik setiap melakukan kegiatan pembelajaran, apakah sebelum melaksanakan pembelajaran, guru sudah terlebih dahulu 
merencanakan perangkat pembelajaran sebagai pedoman atau acuan dalam melaksanakan pembelajaran atau tidak. Hal lain yang mendukung kemampuan guru dalam melaksanakan proses pembelajaran fisika adalah dukungan dari sekolah itu sendiri dengan menyediakan sarana prasarana yang memadai dalam hal ini media pembelajaran. Namun pada kenyataannya hampir semua sekolah subyek penelitian tidak memiliki sarana prasarana yang memadai yang sesuai dengan kebutuhan guru dan siswa.

Suluh dan Dekriati (2019) dalam penelitiannya tentang "Efektifitas Pelaksanaan Kurikulum 2013 ditinjau dari Kesiapan Sekolah dan Pengaruhnya terhadap Perkembangan Sekolah" juga menyatakan bahwa Terkait dengan media pembelajaran, sekolah lebih banyak mengharapkan kreatifitas dan daya juang dari guru untuk menyiapkan sendiri bahan-bahan yang dibutuhkan. Berdasarkan hasil penelitian, secara umum kesiapan sekolah dari sisi ketersediaan sarana dan prasarana dapat dikatakan belum maksimal. Oleh karena itu ini menjadi pertimbangan bersama antara guru sekolah dalam menunjang efektifnya melaksanakan proses pembelajaran di dalam kelas.

\section{F. Hubungan Pengalaman Mengajar dengan}

Kemampuan Guru dalam Merencanakan dan Melaksanakan Proses Pembelajaran Fisika pada Kurikulum 2013

Berdasarkan data pada Tabel 7 diketahui pengalaman mengajar guru tidak berkorelasi dengan kemampuan guru dalam merencanakan dan melaksanakan proses pembelajaran fisika pada kurikulum 2013. Data tabel 7 menunjukkan nilai 0,93 lebih besar dari Taraf Signifikansi 0,05. Artinya tidak ada pengaruh antara pengalaman mengajar dengan kemampuan guru dalam merencanakan dan melaksanakan proses pembelajaran fisika pada kurikulum 2013.

Berdasarkan hasil analisis data tersebut dapat diketahui bahwa pengalaman mengajar guru bukan menjadi suatu tolak ukur bagi guru baik dalam merencanakan maupun melaksanakan proses pembelajaran fisika pada kurikulum 2013. Suksesnya guru melaksanakan proses pembelajaran di dalam kelas tergantung dari bagaimana kesiapan guru sebelum mengajar yaitu dengan mempersiapkan rencana pembelajaran, dan bagimana guru tersebut mampu mengelolah kelas dengan baik apalagi diperhadapkan dengan karakter siswa yang beragam.

\section{G. Kesesuaian Perencanaan Proses Pembelajaran dengan Pelaksanaannya dalam Proses Pembelajaran pada Kurikulum 2013}

Berdasarkan data pada tabel 8 menunjukkan bahwa perencanaan proses pembelajaran yang dilakukan oleh guru tidak berkorelasi dengan pelaksanaan proses pembelajaran di dalam kelas artinya bahwa apa yang telah dirancang dan dipersiapkan oleh guru, tidak sesuai dengan fakta yang terjadi di lapangan. Hal ini disebabkan karena apa yang ditelah dibuat oleh guru dalam rencana pembelajaran (RPP) tidak selalu dijadikan pedoman dalam pelaksanaan proses pembelajaran di dalam kelas. Ini berarti bahwa masih banyak guru yang membuat rencana pembelajaran hanya karena tuntutan kurikulum dan bahkan hanya sebagai formalitas kelengkapan perangkat pembelajaran tetapi jarang menerapkannya saat proses pembelajaran berlangsung. Oleh karena itu perlu disadari oleh guru bahwa pentingnya membuat rencana pembelajaran bagi efektifnya pelaksanaan proses pembelajaran. Semakin lengkap dan baik rencana pembelajaran yang disiapkan maka semakin baik pula pelaksanaannya dalam proses pembelajaran.

\section{KESIMPULAN DAN SARAN}

\section{Kesimpulan}

Berdasarkan data yang telah dikumpulakan, analisis data dan pembahasan, maka kesimpulannya adalah:

1) Pandangan guru terhadap pelaksanaan proses pembelajaran sangat baik.

2) Tidak ada pengaruh yang signifikan antara pengalaman mengajar dengan kemampuan guru merencanakan proses pembelajaran.

3) Tidak ada pengaruh yang signifikan antara pengalaman mengajar dengan kemampuan guru melaksanakan proses pembelajaran.

4) Perencanaan proses pembelajaran belum sepenuhnya sesuai dengan pelaksanaannya dalam proses pembelajaran.

\section{Saran}

Berdasarkan hasil penelitian dan kesimpulan diatas, untuk meningkatkan kualitas pembelajaran dengan berdasarkan beberapa aturan kurikulum yang berlaku, khususnya dalam pelaksanaan proses pembelajaran fisika SMA, maka disampaikan beberapa saran berikut ini:

Bagi Guru. 1) Guru perlu meningkatkan lagi pemahaman tentang pelaksanaan proses pembelajaran baik dalam merencanakan maupun melaksanakan proses pembelajaran, 2) Guru perlu melakukan kegiatan evaluasi untuk melihat 
kembali dan memperbaiki langkah-langkah pembelajaran yang belum maksimal, 3) Guru perlu menyusun perangkat pembelajaran yang lengkap untuk digunakan setiap kali mengajar di kelas, 4) Guru perlu meningkatkan lagi kreatifitas dalam mengelolah media pembelajaran yang dibutuhkan dan sesuai dengan materi yang diajarkan, dan 5) Guru Perlu meningkatkan lagi kemampuannya dalam memilih model-model permbelajaran.

Bagi Kepala Sekolah. Kepala sekolah perlu mengadakan kegiatan evaluasi pelaksanaan proses pembelajaran yang didalamnya membahas tentang penyusunan perangkat pembelajaran dan pelaksanaannya di dalam kelas.

Bagi Dinas Pendidikan. Berdasarkan hasil wawancara dengan beberapa guru, hendaknya dinas pendidikan melakukan kegiatan pelatihan peningkatan kemampuan guru dalam menyusun perangkat pembelajaran sesuai kurikulum yang berlaku disetiap tahun ajaran baru.

\section{Daftar Pustaka}

Ahamdi, Abu. (2001).Ilmu Pendidikan. Jakarta:Rineka Cipta.

Hakim. (2009). Perencanaan Pembelajaran. Bandung: CV.Wacana Prima.

Kemendikbud. (2006). Permendikbud Nomor 22 Tahun 2006 tentang Standar Proses Pendidikan Dasar dan Menengah.

Kurniasi dan Sani. (2015).Sukses Uji Kompetensi Guru-Panduan Lengkap. Surabaya: Kata Pena.

Majid, A. (2009). Perencanaan Pembelajaran. Bandung: PT Remaja Rosdakarya.

Mardapi, D. (2008). Teknik Penyusunan Instrumen Tes dan Nontes.Yogyakarta: Mitra Cendekia Press.

Martiyono. (2012). Perencanaan Pembelajaran: Suatu Strategi Pendekatan Praktis Berdasarkan KTSP termasuk Model T ematik. Yogyakarta: Aswaja Pressindo.

Muh. Sholeh (2017). Perencanaan Pembelajaran Pada Mata Pelajaran Geografi. Tingkat SMA. Jurnal Geografi. 4 (2).

Suluh, \& Ate. (2019). Efektifitas Pelaksanaan Kurikulum 2013 Ditinjau Dari Kesiapan Sekolah Dan Pengaruhnya Terhadap Perkembangan Sekolah. Jurnal Penelitian Pendidikan IPA. (JPPIPA). 5 (2): 248-254

Uno, H. (2008). Perencanaan Pembelajaran. Jakarta: PT Bumi Aksara. 